\title{
Metamorphosis of the estuarine crab Rhithropanopeus harrisii: effect of water type and adult odor
}

\author{
Timothy P. Fitzgerald ${ }^{1}$, Richard B. Forward $\mathrm{Jr}^{1, *}{ }^{*}$ Richard A. Tankersley ${ }^{2}$ \\ ${ }^{1}$ Duke University, Nicholas School of the Environment, Marine Laboratory, 135 Duke Marine Lab Road, Beaufort, \\ North Carolina 28516, USA \\ ${ }^{2}$ Department of Biological Sciences, University of Maryland Baltimore County, 1000 Hilltop Drive, Baltimore, \\ Maryland 21228-5398, USA
}

\begin{abstract}
Larvae of many estuarine crabs are transported to coastal/offshore areas where they develop and subsequently return to the estuary as postlarvae (megalopae), which settle and metamorphose. For these species, it is important for megalopae to be able to differentiate between offshore and estuarine areas as sites for metamorphosis. In contrast, larvae of the crab Rhithropanopeus harrisii (Gould) are retained in estuaries near the adult habitat throughout development. Although previous studies have demonstrated that the rate of metamorphosis of the megalopal stages of several estuarine crabs is accelerated when exposed to estuarine cues, it was hypothesized that metamorphosis of $R$. harrisii postlarvae is not affected by exposure to offshore and estuarine waters but is accelerated by exposure to adult odor cues. Metamorphosis of $R$. harrisii megalopae was accelerated upon exposure to estuarine water and delayed in offshore water at salinities ranging from 5 to 25 PSU. Time to metamorphosis in both water types increased as the salinity decreased. Adult odor also accelerated metamorphosis. Thus, the test hypothesis was only partially supported, and the results indicate that differentiation between offshore and estuarine areas for metamorphosis is common among estuarine crabs regardless of their patterns of larval development.
\end{abstract}

KEY WORDS: Megalopae - Metamorphosis - Settlement - Habitat selection - Chemical cues - Adult odor Rhithropanopeus harrisii

\section{INTRODUCTION}

Larvae of many estuarine crabs are transported seaward, undergo development in coastal areas and return to the estuary as postlarvae (megalopae), which settle and metamorphose in appropriate estuarine sites. In estuaries along the east coast of the United States, this sequence is probably best studied in the blue crab Callinectes sapidus (e.g. Sandifer 1975, McConaugha et al. 1983, Epifanio et al. 1984, Goodrich et al. 1989, De Vries et al. 1994, Olmi 1994) and fiddler crabs Uca sp. (Christy 1982, Christy \& Stancyk 1982, Lambert \& Epifanio 1982, Epifanio et al. 1988). The

\footnotetext{
- Addressee for correspondence.

E-mail: rforward@mail.duke.edu

developmental sequence also underlies the hypothesis proposed by Wolcott \& De Vries (1994) that metamorphosis is delayed by exposure to offshore water but is accelerated by chemical cues associated with estuaries. This hypothesis was developed for blue crabs but applies equally to other brachyuran crab species with similar life histories

In the case of Callinectes sapidus, metamorphosis is delayed by exposure to offshore water (Forward et al. 1994, 1996, 1997, Wolcott \& De Vries 1994, Brumbaugh \& McConaugha 1995) but accelerated by exposure to estuarine water (Forward et al. 1994, 1996), lower salinity (Forward et al. 1994), humic acids (Forward et al. 1997), and cues from estuarine aquatic vegetation such as seagrasses (Forward et al. 1994, 1996), saltmarsh cord grass (Forward et al. 1996) and macroalgae 
(Brumbaugh \& McConaugha 1995, Forward et al. 1996). For Uca sp., cues from estuarine sediment (Christy 1989, O'Connor 1991, O'Connor \& Judge 1997) and adult odor (O'Connor 1991) accelerates metamorphosis and reduces the length of the megalopal stage.

Larvae of the estuarine mud crab Panopeus herbstil do not develop as far seaward as blue crab and fiddler crab larvae and are retained in high salinity regions of estuaries and coastal areas near estuaries (Dittel \& Epifanio 1982, Jones \& Epifanio 1995). Nevertheless, metamorphosis of $P$. herbstii agrees with the hypothesis of Wolcott \& De Vries (1994) in that metamorphosis is delayed in offshore water and accelerated by exposure to sediment from the adult habitat, adult chemical odors, and the estuarine macroalgae Fucus vesiculosus (Weber \& Epifanio 1996).

Alternatively, the entire life cycle of the xanthid mud crab Rhithropanopeus harrisii is completed within estuaries. Adults occur in brackish water areas of estuaries (Williams 1984), while larvae are abundant in the low salinity areas of estuaries (Bousefield 1955, Pinschmidt 1963, Tagatz 1968, Sandifer 1973, 1975. Goy 1976) and rarely found in coastal waters (Nichols \& Keney 1963, Dudley \& Judy 1971). Intensive sampling by Cronin (1982) indicated that all larval stages are retained within the estuary near the adult habitat due to a tidal rhythm in vertical migration (Cronin \& Forward 1979). Since they are rarely exported to coastal areas for larval development, differentiation between ocean and estuarine areas as sites for metamorphosis is unnecessary. However, since juvenile and adult $R$. harrisii are gregarious (Forward pers. obs.) postlarvae should settle and metamorphose in areas with existing adults. Thus, the present study tested the hypothesis that the length of the megalopal stage of $R$. harrisii is unaffected by exposure to offshore and estuarine waters but is shortened by exposure to adult odors. This hypothesis was partially supported, as metamorphosis was accelerated by exposure to both estuarine water and adult odor cues.

\section{MATERIALS AND METHODS}

Collection of adults and rearing of larvae. Ovigerous females of the crab Rhithropanopeus harrisii (Gould) were collected from the Neuse River (North Carolina, USA) between June and August 1997 and maintained in estuarine water (20 PSU; $23^{\circ} \mathrm{C}$ ) on a light:dark cycle that approximated ambient conditions. A salinity of 20 PSU was used because it is near the optimum for larval development (Costlow et al. 1966). 'Estuarine water' was collected off Pivers Island in Beaufort, North Carolina, USA, which is located about $1 \mathrm{~km}$ from the inlet to the Newport River Estuary. Dilutions were made by the addition of deionized water and salinity was measured with a refractometer (American Optical Co.; accuracy \pm 0.5 PSU). Once hatched, zoeae were transferred to glass culture bowls (19 cm diameter) containing new 20 PSU estuarine water. Zoeae were fed brine shrimp nauplii Artemia franciscana Kellogg, which had recently hatched in offshore water. Each brood was maintained in a separate bowl and large broods were divided into 2 or 3 bowls. Larvae were maintained on a $14 \mathrm{~h}$ light: $10 \mathrm{~h}$ dark cycle at $25^{\circ} \mathrm{C}$ using a controlled Environment Chamber (ShererGillett, Model CEL-4). Zoeae were kept in the chamber at all times, except for a brief period daily when they were placed in new 20 PSU estuarine water and fed recently hatched brine shrimp nauplii

Larvae were reared in estuarine water for the first $8 \mathrm{~d}$ of development. The majority of larvae reached Stage III zoeae within this time. They were then transferred to 20 PSU 'offshore water' for the remainder of development to the megalopal stage. The offshore water was collected between 13 and $16 \mathrm{~km}$ seaward of the Newport River Estuary Inlet and diluted to 20 PSU with deionized water. This water was collected from a region beyond the estuarine plume and has previously been shown to lack cues found in estuarine water that accelerate the rate of postlarval development in other crab species (Forward et al. 1994, 1996, 1997). Offshore water was collected at the beginning of each experiment and stored at room temperature in carboys. Thus, during development of the last zoeal stage (IV), larvae were assumed to be in water devoid of estuarine and adult odor cues that could influence the time to metamorphosis of the megalopal stage.

General procedure. The majority of zoeae molted to the megalopae stage between 11 and $13 \mathrm{~d}$ after hatching. Each day, newly molted megalopae from each brood were placed together in a single culture bowl. These megalopae were mixed and haphazardly distributed into experimental treatments. This procedure helped ensure that megalopae from all broods were distributed relatively evenly among the treatments.

The general procedure for all experiments was to test 54 megalopae in each treatment condition. A single megalopa was placed in its own compartment $(3.4 \times 3.4 \times 3 \mathrm{~cm})$ of a plastic box. Each box had $18 \mathrm{com}-$ partments, and each compartment was filled with approximately $15 \mathrm{ml}$ of water containing the test chemical cues (test water) and approximately 30 to 50 brine shrimp nauplii. The megalopae were maintained in the environmental chamber at the same conditions used for rearing (see 'Collection of adults and rearing of larvae'). The test water in the compartments was changed daily and new brine shrimp nauplii were added. The plastic test boxes were washed with distilled water, rinsed, and allowed to air-dry overnight 
between uses. Thus, a box was used every other day for the same treatment.

Experiments. The first of 4 experiments determined if metamorphosis could be accelerated or delayed by environmental chemical cues. The 3 water treatments for this initial experiment were estuarine water, offshore water, and offshore water containing adult odor cues. The salinity for all test solutions was 20 PSU. The latter water was prepared by placing live adult male and female (non-ovigerous) crabs in aerated 20 PSU offshore water at a ratio of $5 \mathrm{~g}$ wet weight $\mathrm{l}^{-1}$ for $24 \mathrm{~h}$. At the end of each incubation period, crabs were removed and the water used immediately for experimentation. New water was prepared daily. Offshore water was the same as that used for rearing larvae and served as the control, since it was assumed to be devoid of estuarine and adult chemical cues. Estuarine water was tested as water containing chemical cues typically found in estuaries such as humic acids (Forward et al. 1997).

The second experiment determined if the effects of estuarine and offshore waters on the development of Rhithropanopeus harrisii postlarvae were influenced by salinity. Megalopae were tested at 3 different salinities $(25,15$, and 5 PSU) using both estuarine and offshore water. For offshore water, target salinities were obtained by adding deionized water. To prevent the dilution of cues in the estuarine water treatments, Neuse River estuarine water (salinity $\approx 7$ PSU) was added to the standard estuarine water (salinity $\approx$ 33 PSU) to achieve salinities of 25 and 15 PSU. For the 5 PSU estuarine water treatment, deionized water was added to the Neuse River estuarine water. New test waters were prepared daily.

The third and fourth experiments tested whether adult Rhithropanopeus harrisii emit chemical odors that accelerate metamorphosis. Offshore water diluted to 20 PSU was used for all treatments for both experiments. Test waters containing different concentrations of adult chemical odors were prepared using the same procedure outlined for Expt 1. Adult crabs (without eggs) were weighed and the appropriate masses were placed in 20 PSU offshore water for $24 \mathrm{~h}$ prior to use. This incubation allowed sufficient time for the offshore water to take on any odors from the adults. All test waters were aerated during the $24 \mathrm{~h}$ of exposure, and new water was prepared daily. The same adult crabs were used for the duration of the experiment and were not fed. Expt 3 tested adult concentrations between 1 and $10 \mathrm{~g} \mathrm{l}^{-1}$. Since all weights had a significant effect on metamorphosis, the experiment was repeated (Expt 4) using concentrations between 0.1 and $1 \mathrm{~g} \mathrm{l}^{-1}$. It was assumed that the resulting odor concentrations were proportional to the adult weight to water volume ratio as has been shown for other marine animals (e.g. Wood 1968).
During all experiments, megalopae were monitored for metamorphosis at $8 \mathrm{~h}$ intervals $(08: 00,16: 00$, and 24:00 h). Experiments continued until all megalopae had molted to the first crab stage (instar). Mortality was rare in the first 2 experiments, as it was below 10\% in each treatment. The last 2 experiments were carried out later in the summer, and mortality in each treatment was about $30 \%$. The time to metamorphosis was measured as the duration of the megalopal stage, i.e. time between molting to the megalopa stage and metamorphosis to the first crab stage. Since no megalopae molted earlier than $3 \mathrm{~d}$, monitoring postlarvae for metamorphosis to the first crab stage began $3 \mathrm{~d}$ after the beginning of each experiment.

Statistical analysis. The effects of various environmental factors on the time to metamorphosis of Rhithropanopeus harrisii megalopae were determined using 1 - and 2-factor analysis of variance (ANOVA). For most experiments, time to metamorphosis values could not be transformed to meet the assumptions of normality and homogeneity of variances among groups. Therefore, the data were rank-transformed prior to analysis using the procedures outlined by Conover \& Iman (1981). Since descriptive statistics of ranked values are often difficult to interpret, means $( \pm \mathrm{SE}$ ) for the original (non-transformed) data are plotted in the figures. When ANOVA results indicated significant treatment effects, treatments were compared using either a Tukey test (for comparison of all treatment combinations) or a Dunnett multiple comparison test (for comparisons of controls with all other treatment groups; Zar 1996). For comparisons using the Dunnett test (i.e. Expts 3 and 4), 1-tailed tests were conducted since initial experiments (i.e. Expt 1) indicated a decrease in the length of the megalopal stage was expected when postlarvae were incubated in the presence of chemical odors from adults.

\section{RESULTS}

\section{Effect of estuarine and adult odor cues}

Results of a 1-way ANOVA revealed that water type (offshore, estuarine, and offshore plus adult odor) had a significant effect on the rate of metamorphosis of Rhithropanopeus harrisii megalopae $(F=12.11$; $\mathrm{df}=$ $2,151 ; \mathrm{p}<0.0001)$. Time to metamorphosis was significantly shorter in both 20 PSU estuarine water and 20 PSU offshore water $+R$, harrisii adult odor compared to 20 PSU offshore water (Tukey multiple comparison test; Fig. 1). There was no significant difference between the rate of metamorphosis of megalopae in estuarine water and offshore water containing $R$. harrisii adult odor cues (Fig. 1). These results suggest 


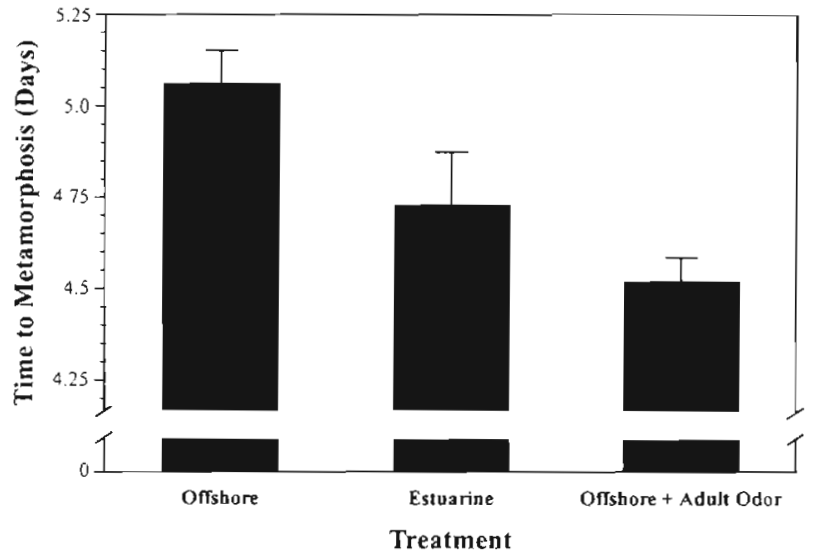

Fig. 1. Rhithropanopeus harrisii. Time to metamorphosis $(\bar{x}+\mathrm{SE})$ for megalopae in offshore water, estuarine water, and offshore water containing adult odor cues. Sample sizes for each treatment ranged between 48 and 54

there are chemical cues present in estuarine water that decrease the duration of the megalopal stage in $R$. harrisii and that adults also release a chemical odor that has a similar effect on the time to metamorphosis.

\section{Effect of water type and salinity}

Since the first experiment demonstrated that Rhithropanopeus harrisii megalopae metamorphose faster in estuarine water as compared to offshore water, the second experiment determined whether the effect of water type on the time to metamorphosis was influ-

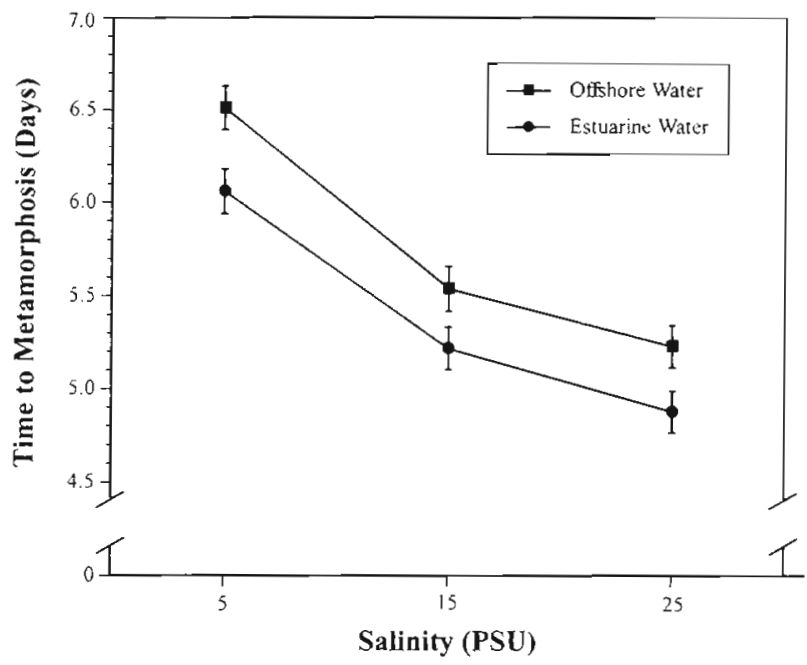

Fig. 2. Rhithropanopeus harrisii. Time to metamorphosis $(\bar{X} \pm \mathrm{SE})$ for megalopae in offshore water and estuarine water at 3 different salinities. Sample sizes for each treatment combination ranged between 43 and 54 enced by salinity (Fig. 2). Results of a 2-way ANOVA indicated that both water type (offshore and estuarine) and salinity $(5,15$, and 25 PSU) had a significant influence on the rate of metamorphosis (water type: $F=19.45 ; \mathrm{df}=1.285 ; \mathrm{p}<0.0001 ;$ salinity: $F=72.59$. $\mathrm{df}=2,285 ; \mathrm{p}<0.0001$ ). For both water types, the time to metamorphosis decreased with increasing salinity and there was no significant interaction between the 2 factors (Fig. $2 ; F=0.136 ; \mathrm{df}=2,285 ; \mathrm{p}>0.5$ ). Thus, megalopae responded in similar ways to changes in salinity, regardless of water type. A rise in salinity resulted in a decrease in the time to metamorphose to the first crab stage (Fig. 2) in both estuarine and offshore water and times were shortest in estuarine water.

\section{Effect of adult odor cues}

Megalopae were found to shorten their time to metamorphosis when exposed to 20 PSU offshore water containing odors from Rhithropanopeus harrisii adults (Fig. 1). The final 2 experiments measured the response of postlarvae to declining concentrations of adult odors. Since it was assumed that odor concentration was proportional to crab weight, different concentrations were generated by incubating different weights of crabs in a fixed volume of offshore water. The control for these experiments was exposure to offshore water, in which crabs were not incubated.

A dose response curve was obtained for adult odor cue concentrations ranging from $1 \mathrm{~g}$ of adult $\mathrm{l}^{-1}$ to $10 \mathrm{~g}$ $\mathrm{l}^{-1}$ (Fig. 3). As expected from Expt 1 (Fig. 1), the addition of adult odors to offshore water had a significant

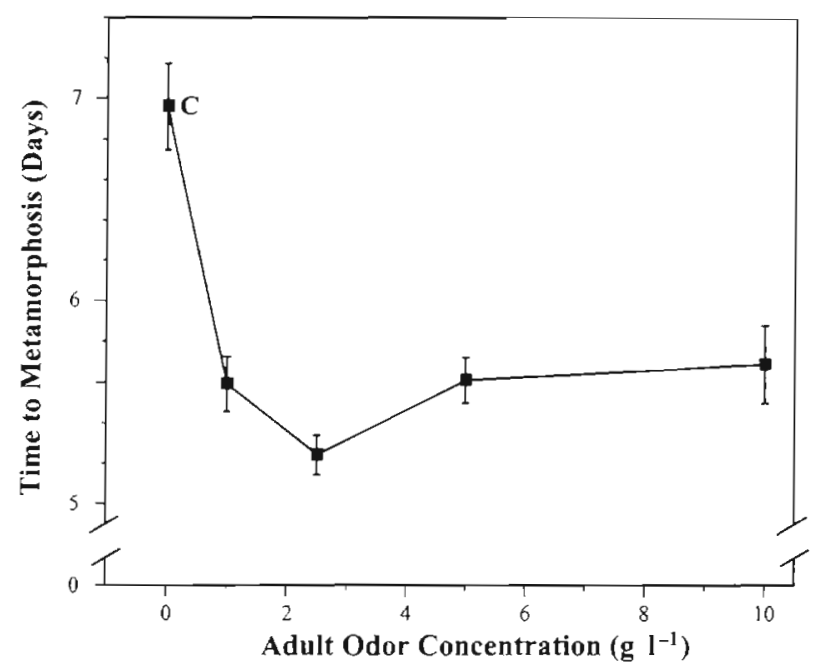

Fig. 3. Rhithropanopeus harrisii. Time to metamorphosis $(\bar{x} \pm S E)$ for megalopae in offshore water $(C$ : control) and offshore water plus odors from adult $R$. harrisii. Sample sizes for each treatment ranged between 35 and 47 


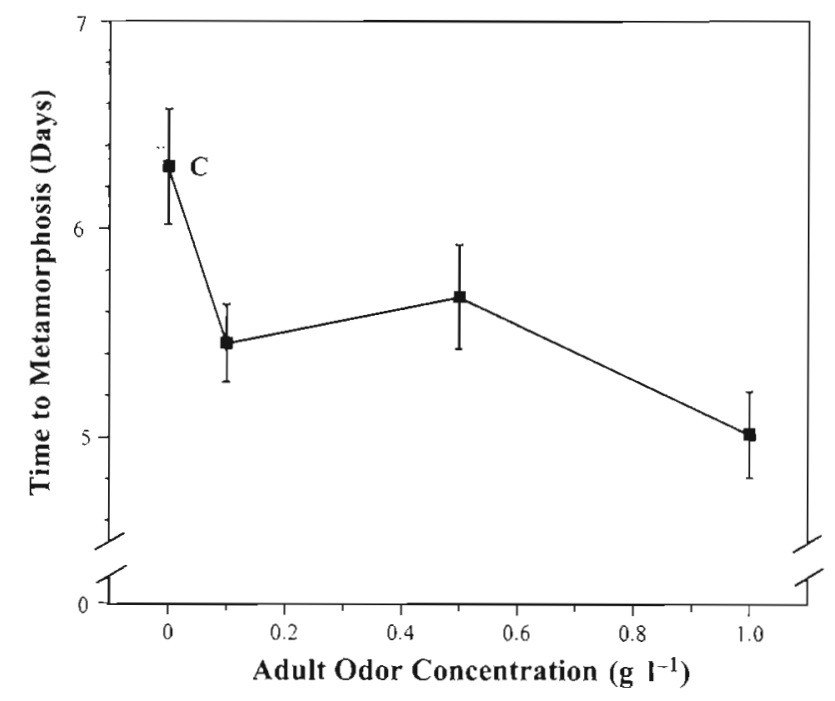

Fig. 4. Rhithropanopeus harrisii. Time to metamorphosis $(\bar{x} \pm \mathrm{SE})$ for megalopae in offshore water (C: control) and offshore water plus odors from adult $R$. harrisii. Sample sizes for each treatment ranged between 39 and 46

effect on the rate of metamorphosis of Rhithropanopeus harrisii megalopae ( $F=16.56$; df $=4,193$; $\mathrm{p}<0.0001)$. Results of a 1-tailed Dunnett comparison test revealed that the time to metamorphosis was significantly shorter in all treatments containing adult odors compared to offshore water alone (control).

Since all treatments in Fig. 3 significantly accelerated the time to metamorphosis, the experiment was repeated with lower concentrations $(0.1$ to $1.0 \mathrm{~g}$ of adult $\mathrm{l}^{-1}$ ) of adult odor, in an attempt to determine the minimum concentration (threshold) necessary to induce a significant decrease in the time to metamorphosis (Fig. 4). Again, there was a significant overall treatment effect for the adult odor cue $(F=6.50$; df $=$ $3,163 ; \mathrm{p}<0.001)$. A Dunnett multiple comparison test (1-tailed) indicated that the rates of metamorphosis for all treatments were significantly different $(p<0.05)$ from the control (offshore water). These results suggest that the threshold concentration for the adult odor cue is less than $0.1 \mathrm{~g} \mathrm{l}^{-1}$.

\section{DISCUSSION}

Adult blue crab Callinectes sapidus (e.g. Sandifer 1975, McConaugha et al. 1983, Epifanio et al. 1984, Goodrich et al. 1989, De Vries et al. 1994, Olmi 1994) and fiddler crabs Uca sp. (Christy 1982, Christy \& Stancyk 1982, Lambert \& Epifanio 1982, Epifanio et al. 1988) inhabit estuaries (Williams 1984) but their larvae develop in coastal/oceanic areas. Transport back into estuaries occurs during the megalopa stage, which subsequently metamorphose in appropriate estuarine sites. Thus, for these species it is important that megalopae be able to differentiate between coastal/oceanic and estuarine areas as sites for metamorphosis. Hence, Wolcott \& De Vries (1994) hypothesized that metamorphosis of blue crab megalopae is delayed in offshore water and accelerated by cues associated with estuaries.

Since larvae and megalopae of the mud crab Rhithropanopeus harrisii are retained in low salinity areas of estuaries (e.g. Cronin 1982), there is no necessity for megalopae to differentiate between offshore and estuarine areas. Thus, it was hypothesized that the rates of development of $R$. harrisii megalopae would be similar in offshore and estuarine waters. The first experiment (Fig. 1) clearly falsified this hypothesis, since metamorphosis was delayed in offshore water and accelerated in estuarine water. This result indicates that even though $R$, harrisii larvae are retained in estuaries, the postlarval stage can differentiate between offshore and estuarine waters and accelerate the time to metamorphosis in response to chemical cues in estuarine water. This species may have the ability to differentiate between offshore and estuarine waters because megalopae may be accidentally transported seaward and delay metamorphosis until they are transported back to an estuarine location. Possible estuarine chemical cues responsible for the accelerated development of $R$. harrisii postlarvae include odors from aquatic vegetation (e.g. Forward et al. 1996) and humic acids (Forward et al. 1997)

The accelerating effect of estuarine water was also evident when megalopae were exposed to different salinities of estuarine and offshore waters (Fig. 2). The time to metamorphosis was always faster in estuarine than offshore water but time decreased as the salinity increased for both water types. Since there was no statistical interaction between salinity and water type (see 'Results'), the decrease in the time to metamorphosis as the salinity increased was due to salinity and not water type. This pattern appears to be consistent among Rhithropanopeus harrisii larval stages, since Costlow et al. (1966) observed a similar increase in the time of development from the first zoeal stage to the first crab stage with a decrease in salinity from 25 to 5 PSU. This relationship may reflect the adverse effects of salinity on development, since mortality also increased as the salinity decreased over the same salinity range (Costlow et al. 1966). This effect of salinity on metamorphosis is the opposite of that for Callinectes sapidus, for which the time to metamorphosis decreased as the salinity of estuarine water decreased (Forward et al. 1994).

Ovigerous Rhithropanopeus harrisii were collected in wire mesh traps containing mollusc shells (Forward 
et al. 1982). $R$. harrisii appear to live gregariously because traps contained large number of males and females of all sizes (Forward pers. obs.). Both the initial experiment (Fig. 1) and the dose/response relationship depicted in Figs. 3 \& 4 indicated that metamorphosis was accelerated by exposure to adult odor. Megalopae were very sensitive to adult odor, since metamorphosis was accelerated by exposure to concentrations of adult odor as low as $0.1 \mathrm{~g}$ of adult $\mathrm{l}^{-1}$ (Fig. 4). These observations suggest that megalopae settle and metamorphose in the presence of conspecifics.

Adult odor also accelerates metamorphosis in UCa pugilator (O'Connor 1991) and Panopeus herbstii (Weber \& Epifanio 1996) but not in Callinectes sapidus (Forward et al. 1994). These species differences may result from adult distributions. Rhithropanopeus harrisii, $U$. pugilator, and $P$. herbstii live as adults in benthic aggregations, whereas C. sapidus is a swimming crab that ranges throughout estuaries (Williams 1984).

Thus, the test hypothesis was partially supported in that metamorphosis of Rhithropanopeus harrisii was accelerated by exposure to adult odor and estuarine water but was delayed in offshore water. Since larval development of $R$. harrisii takes place in estuaries and does not typically include a coastal/oceanic phase or an up-estuary migratory phase, the pattern of delaying metamorphosis in ocean water and acceleration in response to estuarine chemical cues appears to be a common pattern for estuarine crabs regardless of their developmental sequence.

Acknowledgements. This material is based on research supported by the National Science Foundation (Grant No. OCE-9216629). We thank Blythe Gresser for her technical assistance.

\section{LITERATURE CITED}

Bousefield EL (1955) Ecological control of the occurrence of barnacles in the Miramichi estuary. Bull Natn Mus Can Biol Ser 137:1-69

Brumbaugh RD McConaugha JR (1995) Time to metamorphosis of blue crab Callinectes sapidus megalopae: effects of benthic macroalgae. Mar Ecol Prog Ser 129:113-118

Christy JH (1982) Adaptive significance of semilunar cycles of larval release in fiddler crabs (genus: Ucal: test of an hypothesis. Biol Bull (Woods Hole) 163:251-263

Christy JH (1989) Rapid development of megalopae of the fiddler crab Uca pugilator reared over sediment: implications for models of larval recruitment. Mar Ecol Prog Ser 57:259-265

Christy JH, Stancyk SE (1.982) Timing of larval production and flux of invertebrate larvae in a well-mixed estuary. In: Kennedy $V$ (ed) Estuarine comparisons. Academic Press, New York, p 489-503

Conover WJ, Iman RL (1981) Rank transformations as a bridge between parametric and nonparametric statistics. Am Stat 35:124-129

Costlow JD, Bookhout CG, Monroe J (1966) Studies on the larval development of the crab, Rhithropanopeus harrisii
(Gould). I. The effect of salinity and temperature on larval development. Physiol Zool 39:81-100

Cronin TW (1982) Estuarine retention of larvae of the crab Rhithropanopeus harrisii. Estuar Coast Shelf Sci 15:207-220

Cronin TW, Forward RB Jr (1979) Tidal vertical migration: an endogenous rhythm in estuarine crab larvae. Science 205: $1020-1022$

De Vries MC, Tankersley RA, Forward RB Jr, Kirby-Smith WW, Luettich RA (1994) Abundances of crab megalopae are associated with estuarine tidal hydrologic variables. Mar Biol 118:403-413

Dittle AI, Epifanio CE (1982) Seasonal abundance and vertical distribution of crab larvae in Delaware Bay, USA. Estuar Coast Shelf Sci 18:1-12

Dudley DL, Judy MH (1971) Occurrence of larval, juvenile and mature crabs in the vicinity of Beaufort Inlet, North Carolina. NOAA Tech Rep NMFS 637:1-10

Epifanio CE, Little KY, Rowe PM (1988) Dispersal and recruitment of fiddler crab larvae in the Delaware river estuary. Mar Ecol Prog Ser 43:181-188

Epifanio CE, Valenti CC,-Pembroke AE (1984) Dispersal and recruitment of blue crab larvae in the Delaware Bay, USA. Estuar Coast Shelf Sci 18:1-12

Forward. RB Jr, De Vries MC, Rittschof D, Frankel DAZ, Bischoff JP, Fisher CM, WeIch JM (1996) Effects of environmental cues on the metamorphosis of the blue crab Callinectes sapidus Mar Ecol Prog Ser 131:165 177

Forward RB Jr, Frankel DAZ, Rittschof D (1994) Molting of megalopae from the blue crab Callinectes sapidus: effects of offshore and estuarine cues. Mar Ecol Prog Ser 113:55-59

Forward RB Jr, Lohmann K, Cronin TW (1982) Rhythms in larval release by an estuarine crab (Rhithropanopeus harrisii). Biol Bull (Woods Hole) 163:287-300

Forward RB Jr, Tankersley RA, Blondel D, Rittschof D (1997) Metamorphosis of the blue crab Callinectes sapidus: effects of humic acids and ammonium. Mar Ecol Prog Ser 157:277-286

Goodrich DM, van Montfrans J, Orth RJ (1989) Blue crab megalopal influx to the Chesapeake Bay: evidence for a wind-driven mechanism. Estuar Coast Shelf Sci 29:247-260

Goy JW (1976) Seasonal distribution and the retention of some decapod crustacean larvae within the Chesapeake Bay, Virginia. MS thesis, Old Dominion Univ, Norfolk, VA, p 1-334

Jones MB, Epifanio CE (1995) Metamorphosis of brachyuran megalopae in Delaware Bay: an analysis of time series data. Mar Ecol Prog Ser 125:67-76

Lambert R, Epifanio CE (1982) A comparison of dispersal strategies in two genera of brachyuran crab in a secondary estuary. Estuaries 5:182-188

McConaugha JR, Johnson DF, Provenzano AJ, Maris RC (1983) Seasonal distribution of larvae of Callinectes sapidus (Crustacea: Decapoda) in the waters adjacent to Chesapeake Bay. J Crustac Biol 3:582-591

Nichols PR, Keney PM (1963) Crab larvae (Callinectes), in plankton collections from cruises of M/V Theodore N. Gill, south Atlantic coast of the United States, 1953-1954. US Fish Wild Serv Spec Sci Rep Fish 448:1-14

$O^{\prime}$ Connor NJ (1991) Flexibility in timing of the metamorphic molt by fiddler crab megalopae Uca pugilator Mar Ecol Prog Ser 68:243-247

O'Connor NJ, Judge ML (1997) Flexibility in timing of molting of fiddler crab megalopae: evidence of in situ manipulation of cues. Mar Ecol Prog Ser 146:55-60

Olmi EJ III (1994) Vertical migration of blue crab Callinectes sapidus megalopae: implications for transport in estuaries. Mar Ecol Prog Ser 113.39-54 
Pinschmidt WC Jr (1963) Distribution of crab larvae in relation to some environmental conditions in the Newport River estuary, North Carolina. PhD dissertation, Duke University, Durham, NC, p 1-112

Sandifer PA (1973) Distribution and abundance of decapod crustacean larvae in the York River estuary and adjacent lower Chesapeake Bay, Virginia, 1968-1969. Chesapeake Sci 14:235-257

Sandifer PA (1975) The role of pelagic larvae in recruitment to populations of adult decapod crustaceans in York River Estuary and adjacent lower Chesapeake Bay, Virginia. Estuar Coast Mar Sci 3:269-279

Tagatz ME (1968) Biology of the blue crab, Callinectes sapidus Rathbun, in the St. Johns River Florida. US Fish Wildl Serv Fish Bull 67:17-33

Editorial responsibility: Otto Kinne (Editor),

Oldendorf/Luhe, Germany
Weber JC, Epifanio CE (1996) Response of the mud crab (Panopeus herbstii) megalopae to cues from adult habitat Mar Biol 126:655-661

Williams AB (1984) Shrimps, lobsters, and crabs of the Atlantic coast of the Eastern United States, Maine to Florida. Smithsonian Inst Press, Washington, DC

Wolcott DL, De Vries MC (1994) Offshore megalopae of Callinectes sapidus: depth of collection, molt stage and response to estuarine cues. Mar Ecol Prog Ser 109: $157-163$

Wood L (1968) Physiological and ecological aspects of prey selection by the marine gastropod Urosalpinx cinerea (Prosobranchia: Muricidae). Malacologia 6:267-320

Zar JH (1996) Biostatistical analysis. Prentice Hall, Englewood Cliffs, NJ

Submitted: December 11, 1997; Accepted: February 20, 1998 Proofs received from author(s): April 3, 1998 